\title{
Crackdown on tax evasion - improving ways of coordination between the tax authorities and automatic exchange of information developments in Romania
}

\author{
Claudiu IONIȚĂ \\ The Bucharest University of Economic Studies, Bucharest, Romania \\ claudiu.ionita.ro@gmail.com \\ Birol IBADULA \\ The Bucharest University of Economic Studies, Bucharest, Romania \\ birol_ibadula@yahoo.com \\ Cristina VLAD \\ The Bucharest University of Economic Studies, Bucharest, Romania \\ cristina.vlad8@gmail.com \\ Petre BREZEANU \\ The Bucharest University of Economic Studies, Bucharest, Romania \\ brezeanupetre@yahoo.com
}

\begin{abstract}
In an effort to reduce the tax transparency and banking secrecy, the Organisation for Economic Co-operation and Development ("OECD") has been taking the lead on the battle against cross-border tax evasion, seconded by the Internal Revenue Services ("IRS") of the United States of America ("USA"), the G20 and the European Commission. Understanding the power that is brought by information and knowledge, the international community proposed adapting the exchange of information tools that were available to them and extending them to a worldwide level. As a result, the Common Reporting Standard ("CRS") and the Foreign Account Tax Compliance Act ("FATCA") reporting standards were born. This paper aims at analyzing the improvements in automatic exchange of information brought by the CRS and FATCA standards, together with its limitations. An important section of this paper shall be dedicated to the role that Romania plays in the international efforts of fighting tax evasion, together with the tools and procedures developed in order to sustain the reporting standards. In order to analyze the effects of the CRS and FATCA, it is essential to understand the pros and the cons of the international cooperation on tax matters and its available tools before the CRS and FATCA were created. As there is limited previous literature on the subject, the methodology of the research will consist mainly of analyzing the guidelines issued by the international public body representatives and of the current legislative framework. The main finding of the paper can be considered the fact that the new developments in the automatic exchange of information field can represent a huge step forward towards limiting the tax evasion activity, however, one should be reserved due to aspects such as compliance costs, protection of private information, data gathering and processing techniques and tax residency uncertainty. Further analysis is required when the automatic exchange of information results will be available in order to update the reservations of the paper.
\end{abstract}

Keywords: automatic exchange of information, CRS, FATCA, tax evasion, Romania, OECD. 


\section{Introduction}

With estimations ranging up to 8\% (Zucman, 2013) of the total global financial wealth held in jurisdictions considered tax havens due to their unwillingness to cooperate with the tax authorities in fighting tax evasion, the European countries might be looking at a loss in taxable basis of 4,2 trillion dollars in 2013, with the USA not recording 1,1 trillion dollars in 2013. The above figures represent own assessments based on amounts published by the independent company Capgemini Consulting Technology Reporting in the 2016 World Wealth Report. Zucman (Zucman, 2014) estimates that $75 \%$ of the wealth parked in tax havens has not been subject to tax in any country.

Driven by the high stakes, the OECD created the CRS reporting standard and adopted the automatic exchange of information in over 100 jurisdictions. On the other side of the Pacific Ocean, the USA adopts the FATCA in 2010 with the same purpose of combating the tax evasion by automatic exchanging tax information with other jurisdictions.

Romania has agreed to both reporting standards and has developed specific legislation enforcing such standards. As of 2016, financial institutions in Romania are obliged to collect and report to the Romanian Tax Authorities ("RTA"), within certain deadlines, personal information regarding foreign residents that hold financial accounts in Romania. Further on, the RTA will automatically share this information with the Tax Authorities of the country of tax residence.

\section{Literature review}

Most of the literature in the field of automatic exchange of financial information comes from the international institutions and authors specialized in matters of law. Reviewing the limitations of the exchange of information tools was performed up to a certain extent by international authors such as Bacchetta and Espinosa, 2000; Berg and Barba, 2014; Christensen and Tirard, 2016; Hakelberg, 2014; Kerzner and Chodikoff, 2016; Tanzi and Zee, 2000. Some Romanian authors have also contributed to such analysis, such as: Enea and Enea, 2010; Gheorghe, 2015 and Leția, 2015. Nevertheless, the highest quality literature on the subject is provided to the scientific world by the OECD, through a long list of guidelines and targeted reports.

\section{Is a new system necessary? A review of the exchange of information tools and its limitations \\ Double Tax Treaties and Tax Information Exchange Agreements}

Generally, exchange of information clauses exist in the majority of Double Tax Treaties ("DTT"), regardless whether the DTTs where drafted under United Nations ("UN"), United States ("US") or OECD standards. Nevertheless, based on the relevant DTT article, the information requested and received through this inter-administrative tool is deemed difficult to administer as, firstly, competent authorities need to know what information to request and, secondly, the responding competent authorities need to be in possession of such information or have the possibility to obtain such information through official procedures (e.g. tax audits, request of information). This type of exchange of information is described as exchange of information upon request.

The commentaries to the OECD Model Tax Treaty explain that the general rule concerning the exchange of information is that the competent authorities of the Contracting 
States shall exchange such information as is foreseeably relevant to ensure the correct application of the DTT provisions or of the domestic laws of the Contracting States even if, in the latter case, a particular Article of the DTT has not been applied.

The success of the exchange of information upon request is given by the network of DTTs that the country has and its capacity to determine where taxable income is "hidden". As an example, Romania has 87 in-force DTTs, the majority having exchange of information on request clauses. Even with a wide range of DTTs in force, it is not always obvious whether a Romanian tax resident has taxable income generated in one of the countries that would exchange financial information should Romania request such information. And, as mentioned in the Commentaries to the OECD Model Tax Treaty, "fishing expeditions" are not allowed. More so, given the reluctance of some financial institutions to provide information to the competent authorities unless it is mandatory to do so, the competent authorities of some countries find it difficult to gather pertinent information regarding the income derived by non-residents from their territory.

\section{EU Savings Directive}

Another tool used to exchange information is the Council Directive 2003/48/EC

of 3 June 2003 on taxation of savings income in the form of interest payments ("EU Savings Directive"). The purpose of the EU Savings Directive is to allow the interest income derived from one Member State by individual beneficial owners who are tax residents in another Member State to be made subject to tax in accordance with the laws of the Member State of residency.

Through the EU Savings Directive, the agent who pays interest income to nonresident beneficial owners has the obligation to notify the competent tax authorities of his Member State information regarding the beneficial owner and the income derived. Based on the information received from the paying agent, the competent tax authority of that state should automatically exchange the information received with the competent tax authority of the Member State of tax residency of the beneficial owner, in 6 months from the closing of the financial year.

The EU Savings Directive also provides the possibility of Member States to apply transitional rules. During the transitional period, the Member States are not obliged to exchange the information regarding the non-resident beneficial owners but have to levy a withholding tax of $15 \%$ during the first three years, $20 \%$ for the subsequent three years and $35 \%$ thereafter. From the EU Member States, Austria, Luxemburg (until 2015) and Belgium (until 2010) decided to apply the transitional periods.

The EU Savings Directive is also applicable, with transitional rules, in some non-EU Member States and overseas territory. From these countries, the most important countries worth analyzing are Andorra, Liechtenstein, Monaco and, of course, Switzerland, which were widely seen as "tax haven" countries due to the opacity of their banking system.

Following the pressure of the EU Member States, OECD and the Council of Europe, Andorra, Liechtenstein and Switzerland stopped applying the transitional rules as of 1 January 2015 and, as a result, the bank secrecy in Europe received an important blow.

In addition to the reluctance of some States to stop applying the transitional rules, there were some instances when the automatic exchange of information was impaired by hybrid interest bearing products (e.g. interest bearing life insurance products, voluntary pension schemes, etc.) created by some financial institutions and indirect holding vehicles 
(e.g. non-EU trusts, non-EU foundations) used by non-resident beneficial owners of financial accounts, which were out of the scope of the EU Savings Directive. In order to correct these circumventions, the EU Savings Directive was amended in 2014. The Member States have the obligation to transpose the changes in the domestic legislation until 1 January 2016.

\section{Administrative Cooperation Directive}

At its adoption, the Council Directive 2011/16/EU of 15 February 2011 on administrative cooperation in the field of taxation and repealing Directive 77/799/EEC ("Administrative Cooperation Directive") had its main objective to create the framework, rules and procedures for electronic exchange of information that is "foreseeably relevant to the administration and enforcement of the domestic laws of the Member States".

Under the Administrative Cooperation Directive, the exchange of information can be made on request, spontaneously or automatically. Each type of exchange of information has different scopes, rules, procedures and deadlines, reason for which they should be treated separately.

The exchange of information on request generally works within the same limits described under the DTTs and TIEAs. The only important difference is that the exchange of information has to occur within 2 months of the request (if the information is in possession of the authority) or within 6 months (if the information has to be obtained through a tax audit).

As the name implies, the spontaneous exchange of information consists in nonsystematic communication, at any moment and without prior request, of tax information to another Member State. Such non-systematic communication may occur in cases where the competent authority of one Member State has grounds for supposing that there may be a loss of tax revenues in another Member State, either directly or indirectly (through factitious transfer of profits, artificial tax structures, and others). Also, spontaneous exchange of information may happen when a tax reduction or decrease in one State would lead to a potential increase of tax in another State.

The most important tool developed under the Administrative Cooperation Directive is the automatic exchange of information, through which a Member State communicates predefined financial information to another Member State, without prior request, at preestablished regular intervals, regarding the latter State's tax residents. The information exchange under the Directive concerns income derived as of 1 January 2014 and it relates to the following types of income: salary income, director fees, life insurance products who are not in the scope of the EU Savings Directive, pension income and income from immovable property. Such information would have to be automatically exchanged only if the Member States are in possession of it, thus impairing the applicability of the Directive.

Since the Administrative Cooperation Directive was unclear on the type of predefined financial information that should be automatically exchanged and since not all relevant income was included in its scope, in 2014, the Directive was amended. Based on the changes, starting with the income derived as of 1 January 2016, clarifications were brought.

Even if not all types of income are exchanged through the Administrative Cooperation Directive, it is clear that the 2014 changes in the EU Savings Directive and Administrative Cooperation Directive have put a dent in the activity of the tax evaders and 
that the national revenues of the EU Member States are better protected against tax evasion.

Nevertheless, EU tax residents can still decide to invest their money or derive income from third countries (non-EU Member States). At best, the country of destination would have a DTT or TIEA signed with the country of tax residency which would allow for exchange of information on request, which, as mentioned in the sections above, is not necessarily a useful tool if the tax authorities are not aware of the income derived in the other state. Therefore, a new mechanism had to be established in order to include as many non-EU countries as possible, especially with jurisdictions considered as offshore tax havens.

\section{The Common Reporting Standard and Foreign Account Tax Compliance Act}

The CRS and FATCA represent two standards of information that promote cross border tax compliance by implementing an international standard for the automatic exchange of information (scope of application, diligence obligations, type of information exchanged, deadlines for automatic exchange of information and others). While CRS and FATCA have similar characteristics on the surface, there are several differences that need to be taken into account by financial institutions and tax authorities alike.

\section{The Common Reporting Standard}

Developed by the OECD under the Multilateral Competent Authority Agreement on Automatic Exchange of Financial Account Information, the CRS can be seen as an extension of the EU Savings Directive and the Administrative Cooperation Directive to non-EU jurisdictions. The purpose of a Common Reporting Standard across the world is deemed necessary in order to efficiently tackle tax evasion while minimizing compliance costs for governments and businesses.

The standard requires financial institutions to report information on accounts held by non-resident individuals and entities (including trusts and foundations) to their tax administration. The tax administration then securely transmits the information to the account holders' countries of residence on an annual basis.

The type of information included in the scope of the automatic exchange of information is a mix between the information exchanged through the EU Savings Directive and the information exchanged through the Administrative Cooperation Directive. As such, custodial institutions, depository institutions (e.g. banks), investment entities (investment funds) and qualifying insurance companies are considered reporting institutions included in the scope of the CRS exchange of information. Moreover, information on the beneficial owner and nature of the income derived should be provided. Qualifying income is interest income, dividend income, capital gains, income rights related to the capital or to the debt, insurance products with a redemption value and income derived from annuity contracts.

The first wave of automatic exchange of information will be made by 51 countries in September 2017 and will cover income derived as of 1 January 2016. The second wave shall exchange information as of September 2018. In the meanwhile, as the exchange of information under the CRS is mandatory, countries have to create the framework to gather the information to be exchanged under CRS. What is not mandatory under CRM is for 
countries to exchange information with all other signatory countries, each country having to create its own list of selected jurisdictions for automatic exchange of information purposes. Also, what is interesting about the CRS standard is that it has no de minimis limit for reporting obligations to exist.

The Foreign Account Tax Compliance Act

PICBE | 528

Having a much lesser scope than CRS, the reported standard developed by the IRS targets US citizens and US tax residents who hold accounts outside USA. Being a bilateral instrument, almost the same rules would apply for a US financial institution who manage accounts of tax residents of FATCA country partners.

Additionally, less accounts would be subject to exchange of information under FATCA as accounts having a balance of less than 50,000 USD are exempt for reporting purposes. Moreover, pre-existing accounts of less than 50,000 USD (as at 31 December 2015) are not in the scope of the reporting until the balance reaches 1,000,000 USD.

Based on the information provided by the independent consulting company Thomson Reuters, the volume of US persons reported under FATCA would rarely exceed the low thousands, whereas a major UK bank has estimated that $7 \%$ of its customers (several million accounts) will be reportable under CRS. This is generally due to the much stricter due diligence requirements imposed to the reporting entities under CRS.

Under both standards, the pressure is on the shoulders of the reporting agent. The reporting agent has the due diligence obligation to incorporate in his client acceptance procedure information regarding the tax residency of the client or beneficial owner of his client and update it constantly.

\section{How are the Romanian authorities adapting to the fast changing international environment?}

Although not a member of the OECD, Romania has received with great interest the international developments and has been in the front line of the international battle against tax evasion.

This might come as a surprise to many due to Romanian authorities' reluctance to adopt EU and international legislation. Nevertheless, if we analyze the efforts made by the Romanian Tax Authorities in reducing the international tax evasion having an impact on Romanian budget revenues (Figure 1), a conclusion that can be drawn is that Romania has made the crackdown on income tax evasion an important pillar in its tax collection strategy. 


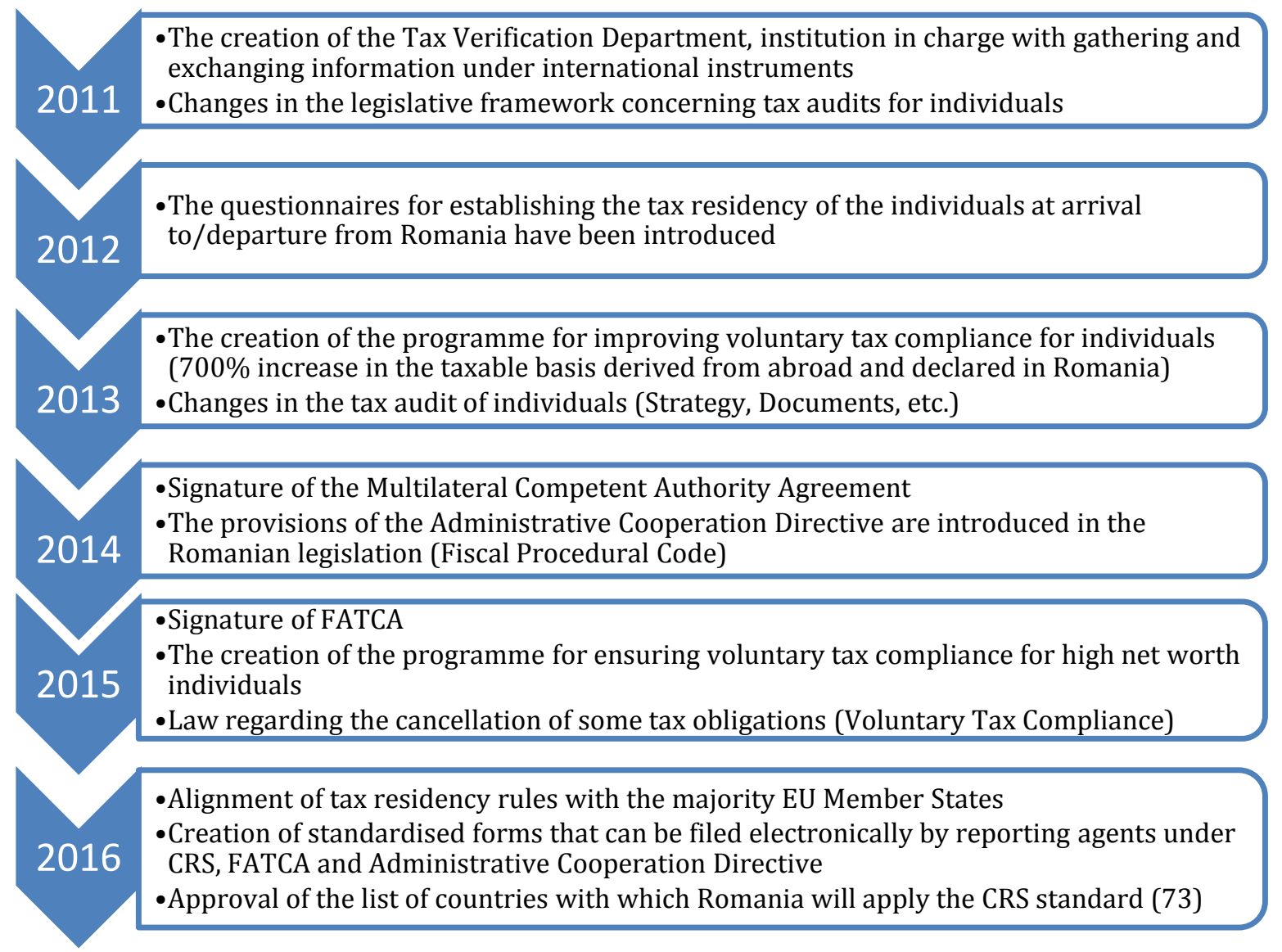

PICBE $\mid 529$

\section{Figure 1. Automatic Exchange of Information developments in Romania}

Source: Authors' own research results.

The Romanian authorities were quick to implement the CRS and FATCA standards in the national legislation and did so in a swift manner. On 24 August 2016, the framework based on which qualifying reporting entities have the obligation to report, by 31 August 2016, the information requested under CRS and FATCA entered into force. Further on, each year, qualifying reporting companies would have to submit the same information to the Romanian Tax Authorities, who will then automatically exchange it with the interested tax authorities of other States.

Under the CRS, Romania will exchange information with 73 countries, out of which many are well-known tax havens. The information shall be exchanged as of September 2017 or September 2018 and will cover the income derived as of 1 January 2016. It is unclear at this stage whether the countries that will start exchanging information as of September 2018 will do so by include qualifying accounts as of 1 January 2016 or as of 1 January 2017.

\section{Conclusion}

Speaking about the importance of war intelligence, US Under Secretary of Defense for Intelligence, Stephen A. Cambone, once said: "one is to ensure that the intelligence analysts get the information that they need when they need it, in a format that's useful to them".

After having analyzed the exchange of information procedures and tools that were available, the conclusion of the research is that, at an international level, a new instrument 
was needed in order to maximize the assessment and collection of taxes that are due on the income derived by the tax residents abroad. The limitations of the instruments available before 2014 were gravely impairing the purpose of the exchange of information, which is to increase tax transparency and limit international tax evasion.

After Switzerland, Liechtenstein and Monaco accepted to stop applying the transitional rules and automatically exchange information regarding the financial income of non-residents (e.g. interest, dividend, capital gains, qualifying insurance products) with the Member States applying the EU Savings Directive, it became clear that concepts such as bank secrecy and tax opacity became yesterday's news and that the time for voluntary tax compliance in Europe has arrived.

Further on, a similar instrument had to appear in order to extend the tax transparency to non-EU countries and, more so, to the tax havens where the majority of non-taxed wealth was parked. After intense pressure made by the OECD, G20 and US (including threats of financial sanctions), the CRS and FATCA standards were received with little resistance by the international community (including well known opaque jurisdictions such as Switzerland, Liechtenstein, Panama or Cayman Islands).

Romania has risen to the challenge and has swiftly developed the technical, legislative and IT framework to sustain both input and output exchange of information through the secure IT network (the CCN system). It remains to be seen whether the information received through the CCN system can be transformed with minimum costs into valuable data by the IT systems of the Romanian Tax Authorities. Otherwise, manual audits of the information received can be difficult to process due to the high number of qualifying accounts (especially under CRS standard).

\section{References}

European Council (2003). Council Directive 2003/48/EC of 3 June 2003 on taxation of savings income in the form of interest payments.

European Council (2011). Council Directive 2011/16/EU of 15 February 2011 on administrative cooperation in the field of taxation and repealing Directive 77/799/EEC.

European Council (2014). Council Directive 2014/48/EU of 24 March 2014 amending Directive 2003/48/EC on taxation of savings income in the form of interest payments.

European Council (2014). Council Directive 2014/107/EU of 9 December 2014 amending Directive 2011/16/EU as regards mandatory automatic exchange of information in the field of taxation.

Government of Romania (2015). Law no. 207/2015 regarding the Fiscal Procedural Code. Official Gazette no. 547 of 23 July 2015.

Government of Romania (2015). Law no. 233/2015 regarding the promulgation of the Agreement between Romania and the United States of America for the enhancement of voluntary tax compliance and for implementing FATCA, signed in Bucharest at 28 May 2015. Official Gazette no. 808 of 30 October 2015.

G20 (2009). The Global Plan for Recovery and Reform. Final Communique of the G20 Summit Held in London on 2 April 2009 (Publication).

OECD (2009). Countering offshore tax evasion: Some Questions and Answers. Paris: OECD Publishing. 
OECD (2014). Standard for Automatic Exchange of Financial Account Information in Tax Matters. Paris: OECD Publishing.

OECD (2014). OECD Model Tax Convention on income and on capital. Paris: OECD Publishing.

OECD (2014). Commentaries to the OECD Model Tax Convention on income and on capital. Paris: OECD Publishing.

OECD (2015). Standard for Automatic Exchange of Financial Account Information in Tax Matters: Implementation Handbook. Paris: OECD Publishing.

Bacchetta, P. \& Espinosa, M. P. (2000). Exchange-of-Information Clauses in International Tax Treaties. International Tax and Public Finance 7 (3), 275-293.

Berg, R. A. \& Barba P. M. (2014). FATCA in Canada: The Restriction on the Class of Entities Subject to FATCA. Canadian Tax Journal 62 (3), 587-633.

Christensen, H., \& Tirard, J. (2016). The amazing development of exchange of information in tax matters: from double tax treaties to FATCA and the CRS. Trusts \& Trustees 22(8), 898-922.

Enea, C. \& Enea, C. (2010). Reflections over the financial crisis and tax heavens influence in launching it. Constantin Brâncuşi University annals, Economy Series 3(1), 247-262.

Gheorghe, C. A. (2015). The End of Banking Secrecy in Post-Crisis Economics- First Step. Logos, Universality, Mentality, Education, Novelty. Section: Law 4(1), 31-39.

Hakelberg, L. (2014). The power politics of international tax co-operation: Luxembourg, Austria and the automatic exchange of information. Journal of European Public Policy 22(3), 409-428.

Kerzner, D. S., \& Chodikoff, D. W. (2016). International Tax Evasion in the Global Information Age. Springer International Publishing 1(1), 283-312.

Leția, A. (2015). Identificarea și combaterea fraudei fiscale în contextul legislative international. Dreptul Bucharest, 11(1), 188-211.

Tanzi, V., \& Zee, H. H. (2000). Taxation in a borderless world: The role of information exchange. Intertax, 28(2), 58-63.

Zucman, G. (2013). The Missing Wealth of Nations: Are Europe and the U.S. net Debtors or net Creditors?. The Quarterly Journal of Economics, 128(3), 1321-1364.

Global Forum members \& observers - Organisation for Economic Co-operation and Development. (n.d.). Retrieved February 7, 2017, from http://www.oecd.org/tax/transparency/about-the-global-forum/members/.

Exchange of information portal. (n.d.). Retrieved February 7, 2017, from http://www.eoitax.org/.

FATCA vs. CRS: The Differences Between FATCA and CRS. (2016, August 02). Retrieved February 7, 2017, from https://tax.thomsonreuters.com/blog/the-differencesbetween-fatca-and-crs/.

Ratings - Organisation for Economic Co-operation and Development. (n.d.). Retrieved February 7, 2017, from http://www.oecd.org/tax/transparency/exchange-ofinformation-on-request/ratings/\#d.en.342263.

World Wealth Report | Compare the data on a global scale. (n.d.). Retrieved February 25, 2017, from https://www.worldwealthreport.com/. 